\title{
Production and Characterization of $\beta$-Glucanase Secreted by the Yeast Kluyveromyces marxianus
}

\author{
Mariana R. Lopes • Carlos J. A. de Souza • Marina Q. R. B. Rodrigues • \\ Daniela A. Costa • Ancély F. dos Santos • Leandro L. de Oliveira • \\ Humberto J. O. Ramos • Valéria M. Guimarães • Wendel B. Silveira • \\ Flávia M. L. Passos • Luciano G. Fietto
}

Received: 12 September 2013 / Accepted: 15 December 2013 /

Published online: 4 January 2014

(C) Springer Science+Business Media New York 2014

\begin{abstract}
An extracellular $\beta$-glucanase secreted by Kluyveromyces marxianus was identified for the first time. The optimal conditions for the production of this enzyme were evaluated by response surface methodology. The optimal conditions to produce $\beta$-glucanase were a glucose concentration of $4 \%(w / v)$, a $\mathrm{pH}$ of 5.5 , and an incubation temperature of $35{ }^{\circ} \mathrm{C}$. Response surface methodology was also used to determine the $\mathrm{pH}$ and temperature required for the optimal enzymatic activity. The highest enzyme activity was obtained at a $\mathrm{pH}$ of 5.5 and a temperature of $55^{\circ} \mathrm{C}$. Furthermore, the enzyme was partially purified and sequenced, and its specificity for different substrates was evaluated. The results suggest that the enzyme is an endo- $\beta-1$, 3(4)-glucanase. After optimizing the conditions for $\beta$-glucanase production, the culture supernatant was found to be effective in digesting the cell wall of the yeast Saccharomyces cerevisiae, showing the great potential of $\beta$-glucanase in the biotechnological production of soluble $\beta$-glucan.
\end{abstract}

Keywords $\beta$-glucanase $\cdot$ Kluyveromyces marxianus $\cdot$ Production $\cdot$ Optimization $\cdot$ Yeast lysis

\section{Introduction}

$\beta$-Glucanases are enzymes that hydrolyze the $\beta$ bonds present in polymers of linear or branched glucose residues. According to the cleavage site in the substrate, they are classified

Mariana R. Lopes and Carlos J. A. de Souza contributed equally to this work.

M. R. Lopes • C. J. A. de Souza • M. Q. R. B. Rodrigues • A. F. dos Santos • H. J. O. Ramos •

V. M. Guimarães $\cdot$ L. G. Fietto $(\bowtie)$

Departamento de Bioquímica e Biologia Molecular, Universidade Federal de Viçosa, Av. PH Rolfs s/n,

Campus universitário, Viçosa, MG 36571-000, Brazil

e-mail: lgfietto@ufv.br

D. A. Costa $•$ W. B. Silveira $•$ F. M. L. Passos

Departamento de Microbiologia, Universidade Federal de Viçosa, Av. PH Rolfs s/n, Campus universitário, Viçosa, MG 36571-000, Brazil

L. L. de Oliveira

Departamento de Biologia Geral, Universidade Federal de Viçosa, Av. PH Rolfs s/n, Campus universitário, Viçosa, MG 36571-000, Brazil 
as exo- or endo-glucanases [1-3]. $\beta$-Glucanases can be classified into four categories: (1) $\beta-1,3, \beta-1,4$-glucanases, which cleave $\beta-1,4$ glycosidic bonds adjacent to $\beta-1,3$ glycosidic bonds; (2) $\beta$-1,4-glucanases, which cleave $\beta$-1,4 glycosidic bonds; (3) $\beta$-1,3(4)-glucanases, which cleave polymers of $\beta$-1,3-1,4-glucan and $\beta$-1,3-glucan; and (4) $\beta$-1,3-glucanases, which cleave the glucosidic linkages in $\beta$-1,3-glucan [4-7].

$\beta$-Glucanases have great biotechnological potential. They are used in a variety of industrial applications, such as an additive in animal feed $[8,9]$. They are also employed in biological pest control due their ability to cleave the cell walls of pathogenic microorganisms and in obtaining bioactive oligosaccharides, $\beta$-glucan in particular, which is considered a potent immunomodulator [10-13]. $\beta$-Glucan has been shown to possess antitumor, antiinflammatory, antimutagenic, hypocholesterolemic, and hypoglycemic activities and to protect organisms against infection [14-17]. Kim and Yun [18] demonstrated that the $\beta$-glucan obtained from the yeast cell wall appears to be more effective than that obtained from other sources. Thus, Saccharomyces cerevisiae, a yeast widely used in industrial fermentation processes, is a major source of bioactive $\beta$-glucan [19].

The biological activity of a polysaccharide is related to its molecular weight, configuration, and glycosidic linkages, among other characteristics [20]. Acid hydrolysis has been the most widely used route to obtain oligosaccharides; however, this method yields a large amount of mono-, di-, and trisaccharides as well as by-products, such as furfural. For this reason, the enzymatic hydrolysis of $\beta$-glucan has been evaluated to obtain different glucooligosaccharides as it allows the production of higher molecular weight oligomers (degree of polymerization $\geq 4$ ) [17]. In this context, enzymatic lysis of the yeast cell wall using $\beta$-glucanase has a potential application in the treatment of residual cell mass to obtain $\beta$ glucan in the fermentation industry.

Kluyveromyces marxianus shows some interesting traits that would be useful in industrial applications, including the capacity to grow in a wide variety of substrates and at high temperatures [21], a high specific growth rate, and a natural ability to secrete enzymes, which is a desired property for the cost-effective industrial process. Moreover, different strains of $K$. marxianus have generally recognized as safe status, similar to $S$. cerevisiae and Kluyveromyces lactis [21].

In this study, a new extracellular $\beta$-glucanase produced by $K$. marxianus was identified in addition to the intracellular $\beta$-glucosidase that has been previously described for this yeast [22, 23]. Response surface methodology was used to optimize the production process and to determine the optimal parameters ( $\mathrm{pH}$ and temperature) for its enzymatic activity. Furthermore, after optimizing the conditions for $\beta$-glucanase production, the resulting culture supernatant was found to be effective in digesting the cell wall of the yeast $S$. cerevisiae, indicating the great potential of this enzyme in the biotechnological production of soluble $\beta$-glucan and protoplasts from yeast cells.

\section{Materials and Methods}

\section{Microorganisms and Growth Conditions}

The yeast $K$. marxianus UFV-3 was maintained on YPD agar medium (10 g/L yeast extract, $20 \mathrm{~g} / \mathrm{L}$ peptone, $20 \mathrm{~g} / \mathrm{L}$ glucose, and $20 \mathrm{~g} / \mathrm{L}$ agar) at $28{ }^{\circ} \mathrm{C}$ and subcultured at nightly intervals. The media used for enzyme production consisted of $1 \mathrm{~g} / \mathrm{L}$ yeast extract and $2 \mathrm{~g} / \mathrm{L}$ peptone $(0.1 \times \mathrm{YP})$, containing different glucose and Tween 20 concentrations and $\mathrm{pH}$ values, as indicated by the factorial design (Table 1). The $\mathrm{pH}$ of the medium was kept constant by 
Table 1 Central composite experimental design matrix defining conditions for optimization of $\beta$-glucanase production by $K$. marxianus grown in shake flasks: influence of concentrations of glucose, Tween 20 , medium $\mathrm{pH}$, and temperature of growth and respective observed and adjusted values for enzyme activity (units per milliliter) and residuals

\begin{tabular}{|c|c|c|c|c|c|c|c|}
\hline \multirow[t]{2}{*}{ Treatment } & \multicolumn{4}{|c|}{ Independent variables } & \multirow{2}{*}{$\begin{array}{l}\text { Enzymatic activity } \\
(\mathrm{U} / \mathrm{mL})\end{array}$} & \multirow[t]{2}{*}{$\hat{y}(\mathrm{U} / \mathrm{mL})$} & \multirow[t]{2}{*}{$\varepsilon$} \\
\hline & $\begin{array}{l}\text { Temperature } \\
\left({ }^{\circ} \mathrm{C}\right)\end{array}$ & $\mathrm{pH}$ & $\begin{array}{l}\text { Tween } 20 \\
(\% v / v)\end{array}$ & $\begin{array}{l}\text { Glucose } \\
(\% w / v)\end{array}$ & & & \\
\hline 1 & $31.5(-1)$ & $4.75(-1)$ & $0.05(-1)$ & $3.0(-1)$ & 5.23 & 5.6984 & -0.46983 \\
\hline 2 & $38.5(+1)$ & $4.75(-1)$ & $0.05(-1)$ & $3.0(-1)$ & 7.04 & 6.1205 & 0.92111 \\
\hline 3 & $31.5(-1)$ & $6.25(+1)$ & $0.05(-1)$ & $3.0(-1)$ & 4.10 & 5.1915 & -1.09269 \\
\hline 4 & $38.5(+1)$ & $6.25(+1)$ & $0.05(-1)$ & $3.0(-1)$ & 2.73 & 5.6137 & -2.88416 \\
\hline 5 & $31.5(-1)$ & $4.75(-1)$ & $0.15(+1)$ & $3.0(-1)$ & 5.13 & 5.6137 & -2.88416 \\
\hline 6 & $38.5(+1)$ & $4.75(-1)$ & $0.15(+1)$ & $3.0(-1)$ & 6.68 & 6.1205 & 0.55798 \\
\hline 7 & $31.5(-1)$ & $6.25(+1)$ & $0.15(+1)$ & $3.0(-1)$ & 4.43 & 5.1915 & -0.76613 \\
\hline 8 & $38.5(+1)$ & $6.25(+1)$ & $0.15(+1)$ & $3.0(-1)$ & 2.81 & 5.6137 & -2.80851 \\
\hline 9 & $31.5(-1)$ & $4.75(-1)$ & $0.05(-1)$ & $5.0(+1)$ & 4.22 & 6.7505 & -2.52818 \\
\hline 10 & $38.5(+1)$ & $4.75(-1)$ & $0.005(-1)$ & $5.0(+1)$ & 4.22 & 6.7505 & -2.52818 \\
\hline 11 & $31.5(-1)$ & $6.25(+1)$ & $0.05(-1)$ & $5.0(+1)$ & 5.39 & 6.6659 & -1.27342 \\
\hline 12 & $38.5(+1)$ & $6.25(+1)$ & $0.05(-1)$ & $5.0(+1)$ & 5.39 & 6.6659 & -1.27342 \\
\hline 13 & $31.5(-1)$ & $4.75(-1)$ & $0.15(+1)$ & $5.0(+1)$ & 4.31 & 6.7505 & -2.43992 \\
\hline 14 & $38.5(+1)$ & $4.75(-1)$ & $0.15(+1)$ & $5.0(+1)$ & 6.92 & 7.1727 & -0.25212 \\
\hline 15 & $31.5(-1)$ & $6.25(+1)$ & $0.15(+1)$ & $5.0(+1)$ & 4.87 & 6.2437 & -1.37702 \\
\hline 16 & $38.5(+1)$ & $6.25(+1)$ & $0.15(+1)$ & $5.0(+1)$ & 6.54 & 6.6659 & -0.12351 \\
\hline 17 & $28.0(-\alpha)$ & $5.5(0)$ & $0.10(0)$ & $4.0(0)$ & 6.11 & 3.3950 & 2.71610 \\
\hline 18 & $42.0(+\alpha)$ & $5.5(0)$ & $0.10(0)$ & $4.0(0)$ & 5.12 & 4.2394 & 0.88071 \\
\hline 19 & $35.0(0)$ & $4.0(-\alpha)$ & $0.10(0)$ & $4.0(0)$ & 3.21 & 2.8690 & 0.33834 \\
\hline 20 & $35.0(0)$ & $4.0(-\alpha)$ & $0.10(0)$ & $4.0(0)$ & 5.11 & 1.8553 & 3.25848 \\
\hline 21 & $35.0(0)$ & $5.5(0)$ & $0.00(-\alpha)$ & $4.0(0)$ & 13.45 & 10.8913 & 2.56308 \\
\hline 22 & $35.0(0)$ & $5.5(0)$ & $0.20(+\alpha)$ & $4.0(0)$ & 10.76 & 10.8913 & 2.56308 \\
\hline 23 & $35.0(0)$ & $5.5(0)$ & $0.10(0)$ & $2.0(-\alpha)$ & 8.36 & 6.6056 & 1.75617 \\
\hline 24 & $35.0(0)$ & $5.5(0)$ & $0.10(0)$ & $6.0(+\alpha)$ & 10.55 & 8.7100 & 1.84065 \\
\hline 25 & $35.0(0)$ & $5.5(0)$ & $0.10(0)$ & $4.0(0)$ & 10.75 & 10.8913 & -0.14272 \\
\hline 26 & $35.0(0)$ & $5.5(0)$ & $0.10(0)$ & $4.0(0)$ & 11.41 & 10.8913 & 0.52302 \\
\hline 27 & $35.0(0)$ & $5.5(0)$ & $0.10(0)$ & $4.0(0)$ & 11.37 & 10.8913 & 0.47763 \\
\hline 28 & $35.0(0)$ & $5.5(0)$ & $0.10(0)$ & $4.0(0)$ & 11.10 & 10.8913 & 0.09937 \\
\hline 29 & $35.0(0)$ & $5.5(0)$ & $0.10(0)$ & $4.0(0)$ & 10.99 & 10.8913 & 0.09937 \\
\hline
\end{tabular}

addition of $50 \mathrm{mM}$ sodium citrate buffer. Erlenmeyer flasks $(150 \mathrm{~mL})$ containing $50 \mathrm{~mL}$ of culture medium were inoculated by adding yeast pre-culture to an $\mathrm{OD}_{600}$ of 0.6 and incubated at different temperatures on a rotary shaker $(180 \mathrm{rpm})$ for $48 \mathrm{~h}$.

\section{Enzyme Assays}

Cell-free supernatants were obtained by centrifugation of freshly grown yeast cultures and used as the source of extracellular $\beta$-glucanase. The enzymatic activities of the supernatants were determined using $p$-nitrophenyl- $\beta$-D-glucopyranoside ( $p$-NPG, Sigma) as a substrate. 
The $p$-NPG-hydrolyzing activity was estimated by incubating $0.250 \mathrm{~mL}$ of each supernatant with $0.250 \mathrm{~mL}$ of $2 \mathrm{mM} p$-NPG in $0.05 \mathrm{M}$ sodium citrate buffer $(\mathrm{pH} 5.5)$ at $50{ }^{\circ} \mathrm{C}$ for $40 \mathrm{~min}$. The reaction was stopped by the addition of $1.0 \mathrm{~mL}$ of $0.5 \mathrm{M} \mathrm{Na}_{2} \mathrm{CO}_{3}$. The release of $p$-nitrophenol was determined at $410 \mathrm{~nm}$ using the molar extinction coefficient $(\varepsilon)$ $18,300 \mathrm{M}^{-1} \mathrm{~cm}^{-1}$. The enzyme activity was expressed in units per milliliter, and one unit (U) was defined as the nanomoles of $p$-nitrophenol released per minute.

\section{Optimization of Enzyme Production}

A central composite design with four independent variables (concentration of glucose, concentration of Tween 20, $\mathrm{pH}$ of the medium, and incubation temperature) was examined for the shake flask cultivation of $K$. marxianus UFV-3. The effects of these factors on the production of extracellular $\beta$-glucanase by this yeast strain were evaluated using a central composite experimental design $\left(2^{4}+2 \times 4+5\right)$ with five replicates at the central point, summarizing 25 different combinations and 29 experimental runs. The independent variables and respective levels of variation for $\beta$-glucanase production ( $Y_{1}=$ units per milliliter) are shown in Table 1. Analysis of variance (ANOVA) and multiple regression analysis were performed using Minitab 16 software, and surface plots were constructed using SigmaPlot 10.0 software.

\section{Optimization of Enzyme Activity}

The yeast $K$. marxianus UFV-3 was grown for $48 \mathrm{~h}$ in $0.1 \times \mathrm{YP}$ under the conditions determined by the experimental optimization. After centrifugation $(10,000 \times g$ for $10 \mathrm{~min})$, the cell-free supernatant was characterized for $\beta$-glucanase activity. To evaluate the effect of temperature, the supernatant was incubated with the substrate $p$-NPG at 28, 37, 42, 50, 55, 60, 65 , or $70^{\circ} \mathrm{C}$. To evaluate the effect of $\mathrm{pH}$, the enzymatic activity assays were performed using McIlvaine buffer (citrate/phosphate) with $\mathrm{pH}$ values ranging from 3.0 to 7.5 (0.5 intervals). Based on these results, a factorial experiment was devised for the optimization of enzyme activity using a central composite design $\left(2^{2}+2 \times 2+5\right)$ with five replicates at the central point, summarizing eight different combinations and 13 experimental runs. The independent variables and respective levels of $\beta$-glucanase activity $\left(Y_{1}=\right.$ units per milliliter) are shown in Table 2. ANOVA and multiple regression analysis were performed using Minitab 16 software, and surface plots were constructed using SigmaPlot 10.0 software.

\section{Partial Purification of the Extracellular $\beta$-Glucanase}

The extracellular $\beta$-glucanase was purified by ion exchange chromatography. First, a crude extract was obtained by growing the yeast $K$. marxianus UFV-3 under the optimal conditions determined from the response surface analysis. The extract was concentrated by ultrafiltration using a Vivaspin column (10 kDa molecular weight cutoff (MWCO), GE Healthcare) at $4,500 \times g$ to a final concentration of $10 \%$ of the initial volume. The concentrated crude extract was adjusted to a $\mathrm{pH}$ of 7.0 and then subjected to anion exchange liquid chromatography using a HiTrap Capto Q column (GE Healthcare) that was previously equilibrated with $50 \mathrm{mM}$ sodium phosphate buffer $(\mathrm{pH} 7.0)$ at a flow rate of $1.0 \mathrm{~mL} /$ min. Stepwise elution was performed with $\mathrm{NaCl}$ concentrations from 0.1 to $1 \mathrm{M}$. The fractions that were positive for enzyme activity were pooled and concentrated using a Vivaspin column (10 kDa MWCO, GE Healthcare). For all steps, the enzyme assay was performed and the concentration of total soluble protein was determined by the bicinchoninic acid method [24]. 
Table 2 Central composite experimental design matrix defining conditions for optimization of $\beta$-glucanase activity: effect of $\mathrm{pH}$ and temperature and respective observed and adjusted values for enzyme activity (units per milliliter) and residuals

\begin{tabular}{|c|c|c|c|c|c|}
\hline \multirow[t]{2}{*}{ Treatment } & \multicolumn{2}{|c|}{ Independent variables } & \multirow{2}{*}{$\begin{array}{l}\text { Enzymatic activity } \\
(\mathrm{U} / \mathrm{mL})\end{array}$} & \multirow[t]{2}{*}{$\hat{y}(\mathrm{U} / \mathrm{mL})$} & \multirow[t]{2}{*}{$\varepsilon$} \\
\hline & Temperature $\left({ }^{\circ} \mathrm{C}\right)$ & $\mathrm{pH}$ & & & \\
\hline 1 & $40.0(-1)$ & $4.5(-1)$ & 25.22 & 16.59 & -0.84 \\
\hline 2 & $40.0(-1)$ & $6.5(+1)$ & 12.24 & 20.82 & 4.40 \\
\hline 3 & $66.0(+1)$ & $4.5(-1)$ & 12.36 & 14.07 & -1.83 \\
\hline 4 & $66.0(+1)$ & $6.5(+1)$ & 41.32 & 20.67 & 0.67 \\
\hline 5 & $53.0(0)$ & $4.0(-\alpha)$ & 21.35 & 10.55 & 0.84 \\
\hline 6 & $53.0(0)$ & $7.0(+\alpha)$ & 11.39 & 44.54 & -2.22 \\
\hline 7 & $35.0(-\alpha)$ & $5.5(0)$ & 15.75 & 44.54 & -2.74 \\
\hline 8 & $71.0(+\alpha)$ & $5.5(0)$ & 8.73 & 44.54 & -3.13 \\
\hline 9 & $53.0(0)$ & $5.5(0)$ & 42.32 & 18.34 & -5.98 \\
\hline 10 & $53.0(0)$ & $5.5(0)$ & 41.80 & 27.82 & 13.50 \\
\hline 11 & $53.0(0)$ & $5.5(0)$ & 41.41 & 44.54 & 0.17 \\
\hline 12 & $53.0(0)$ & $5.5(0)$ & 44.71 & 44.54 & 1.59 \\
\hline 13 & $53.0(0)$ & $5.5(0)$ & 46.13 & 13.15 & -4.42 \\
\hline
\end{tabular}

Protein Digestion and Identification by Mass Spectrometry (MS)

\section{Protein Digestion}

Protein spots were removed manually from the gels, reduced with DTT, and alkylated with iodoacetamide. The digestion was carried out with trypsin in $50 \mathrm{mM}$ ammonium bicarbonate buffer (pH 7.8) containing $20.0 \mathrm{ng} / \mu \mathrm{L}$ sequencing grade trypsin (Promega) at $37^{\circ} \mathrm{C}$ overnight. Peptides were extracted from the spots with $30 \mu \mathrm{L}$ of $50 \mathrm{mM}$ ammonium bicarbonate, followed by incubation for $10 \mathrm{~min}$ with occasional vortex mixing. The supernatant was collected and transferred to a $0.5-\mathrm{mL}$ plastic microcentrifuge tube. This extraction was performed two more times. The extract was completely dried by evaporation in a SpeedVac. The tryptic peptides were solubilized in $30 \mu \mathrm{L}$ of MS grade water (Sigma-Aldrich) containing $0.1 \%(v / v)$ formic acid.

\section{Protein Identification and Sequencing}

Matrix-assisted laser desorption/ionization-time of flight mass spectrometer (MALDI-TOF)/ TOF (Ultraflex III, Bruker Daltonics) and quadrupole-time-of-flight (Q-TOF) (micrOTOF-Q III, Bruker Daltonics) were used to analyze the proteins. For MALDI-TOF/TOF mass spectrometry, the tryptic peptides were mixed with $\alpha$-cyano-4-hydroxyl cinnamic acid (Bruker Daltonics) at a 1:1 ratio. The mass spectra obtained were processed using Flexi Analysis software (Bruker Daltonics), and a peak list (mascot generic format (mgf) format) was used for peptide mass fingerprinting and de novo sequencing.

For Q-TOF, $10 \mu \mathrm{L}$ of the tryptic digest was used for LC-MS analysis using a HPLC system (Prominence UFLC, Shimadzu) and a C18 capillary column (5 A, $300 \mu \mathrm{m} \times 100 \mathrm{~mm}$ ) at a flow rate of $3.0 \mu \mathrm{L} / \mathrm{min}$. The eluted peptides were injected into a micrOTOF-Q mass spectrometer using a micro-ESI ionization needle. The mobile phase buffers used for the gradient program 
were water with $0.1 \%(v / v)$ formic acid (A) and acetonitrile with $0.1 \%(v / v)$ formic acid (B). The gradient program consisted of $5 \% \mathrm{~B}$ for $5 \mathrm{~min}$, linear ramping to $50 \%$ B over $35 \mathrm{~min}$, linear ramping to $95 \% \mathrm{~B}$ over $10 \mathrm{~min}$, holding at $95 \% \mathrm{~B}$ for $10 \mathrm{~min}$, ramping back to $5 \% \mathrm{~B}$ over $5 \mathrm{~min}$, and, finally, holding at $5 \% \mathrm{~B}$ for $5 \mathrm{~min}$. The mass spectrometer scanned between 300 and 1,500 $\mathrm{m} / \mathrm{z}$ in positive mode, and data were acquired for $70 \mathrm{~min}$ for each LC-MS/MS run. Data acquisition by both MS instruments was managed using the Hystar package (Bruker), and the spectrums were processed with the Data Analysis package (Bruker) using the default settings for proteomics. The mass spectrometer operated in auto-MSn mode, which collected MS2 spectra for the more intense ions in each full scan spectrum, excluding single charge ions. The scan time was set to $0.5 \mathrm{~s}$ for the survey scan, and the MS2 spectra were recorded for five spectrums to enable the collection of the maximum number of MS2 spectra during the analysis. Peak lists were generated in an mgf by the Data Analysis package (Bruker) and used for protein identification with the Mascot algorithm (Matrix Science). Batch Mascot searches were performed locally against the protein database from NCBI using the Mascot Daemon client with a precursor tolerance of $0.1 \mathrm{Da}$ for the product ions, allowing for methionine oxidation and deamidated (NQ) as a variable modification, carbamido methylation as a fixed modification, one missed cleavage, charge states of 2,3 , and 4, and trypsin as the enzyme. The peptide and protein identifications were statistically evaluated and validated using the PeptideProphet and ProteinProphet algorithms from the Scaffold package (Proteome software) using a threshold of $>90 \%$ probability. The sequences were verified manually by de novo sequencing.

\section{Enzyme Specificity to Different Substrates}

To determine the specificity of the enzyme on various chromogenic substrates, the partially purified $\beta$-glucanase was used in the enzymatic reaction described above with each of the following substrates: $p$-nitrophenyl ( $p$ NP) $\beta$-D-glucopyranoside, $p$ NP- $\beta$-D-mannopyranoside, $p \mathrm{NP}-\beta$-D-galactopyranoside, $p \mathrm{NP}-\beta$-D-xylopyranoside, $p \mathrm{NP}-\beta$-cellobioside, $p \mathrm{NP}-\alpha$ glucopyranoside, $p \mathrm{NP}-\alpha$-mannopyranoside, $p \mathrm{NP}-\alpha$-D-galactopyranoside, $p \mathrm{NP}-\alpha$-Larabinopyranoside, $o$-nitrophenyl (oNP) $\beta$-D-glucopyranoside, oNP- $\alpha$-D-galactopyranoside, and $m$-nitrophenyl (mNP) $\alpha$-D-galactopyranoside.

The concentrated culture supernatant was used to test the enzyme activity on cellobiose, carboxymethylcellulose, and $\beta$-glucan. To measure the enzyme activity on cellobiose, the enzyme extract was incubated with $100 \mathrm{mM}$ cellobiose in $50 \mathrm{mM}$ citrate buffer ( $\mathrm{pH} \mathrm{5.5)}$ at 37, 42 , or $50{ }^{\circ} \mathrm{C}$ for $30 \mathrm{~h}$. Aliquots were withdrawn every $6 \mathrm{~h}$ and boiled for $5 \mathrm{~min}$. The glucose released was measured by HPLC. To measure the enzyme activity on carboxymethyl cellulose $(\mathrm{CMC})$ and $\beta$-glucan, the reaction was incubated for $4 \mathrm{~h}$ at $50{ }^{\circ} \mathrm{C}$ in a total volume of $750 \mu \mathrm{L}$, which contained $225 \mu \mathrm{L}$ of sample, $375 \mu \mathrm{L}$ of $2 \%(w / v) \mathrm{CMC}$ or $\beta$-glucan, and $150 \mu \mathrm{L}$ of $50 \mathrm{mM}$ sodium citrate buffer ( $\mathrm{pH}$ 5.5). The reducing sugar released was quantified using the dinitrosalicylic acid method [25]. Furthermore, the glucose concentration was also determined in this assay using HPLC.

\section{Lytic Activity Against S. cerevisiae}

Lytic activity was quantified by measuring the $\mathrm{OD}_{600}$ of a cell suspension of $S$. cerevisiae in the presence and absence of the enzyme. Yeast cells were collected by centrifugation, washed with $50 \mathrm{mM}$ citrate buffer ( $\mathrm{pH}$ 5.5), and suspended in the same buffer to an OD of 1.4. Enzyme activity assays were performed using $50 \mu \mathrm{L}$ of the crude extract concentrate with or without $50 \mathrm{mM} \beta$-mercaptoethanol and $50 \mu \mathrm{L}$ of yeast culture (final OD of 0.7 ). The assay was performed for $16 \mathrm{~h}$ at $45^{\circ} \mathrm{C}$ in microplates. 


\section{Results and Discussion}

\section{Optimization of $\beta$-Glucanase Production}

Factorial design and response surface methodology are efficient strategies to obtain optimal conditions for systems containing multiple variables [26]. These techniques have been successfully employed in several areas of biotechnology, especially in the optimization of culture media for enzyme production [27, 28] and in the optimization of conditions that favor enzymatic activity $[29,30]$. Thus, to optimize the production of extracellular $\beta$-glucanase by $K$. marxianus UFV-3, these techniques were used to determine the relationship of enzyme production with the following controllable factors: $\mathrm{pH}$, temperature, Tween 20 concentration, and glucose concentration. The range of values tested for each factor was determined according to the literature for Tween 20 , as well as from data that were previously obtained by our laboratory (data not shown). Table 1 shows the combinations of factors, the levels assayed, and the respective observed and adjusted $(\widehat{y})$ activity (units per milliliter) of the secreted $\beta$-glucanase and the residual error obtained for each treatment.

Multiple regression analysis of the experimental data enabled the creation of a second-order polynomial model for $K$. marxianus extracellular $\beta$-glucanase production (Eq. 1).

$$
\mathrm{EA}=-295.92+10.1661 T+41.3599 P+6.99310 G-0.144369 T^{2}-3.79071 P^{2}-0.808376 G^{2}
$$

where EA corresponds to enzymatic activity (units), $T$ corresponds to temperature, $P$ corresponds to the $\mathrm{pH}$ of the medium, and $G$ corresponds to the concentration of glucose.

All of the effect terms in Eq. 1 significantly influenced $(p<0.05)$ the extracellular $\beta$-glucanase activity. The linear and squared effect terms for the Tween 20 concentration and the effect terms for the interactions between the experimental factors were discarded because they were not significant according to the $t$ test $(p>0.05)$. The model showed a $R^{2}$ of $73.53 \%$, indicating that most of the variation observed in the extracellular $\beta$-glucanase production could be explained using the adjusted model.

The response surface and contour plots of the adjusted extracellular $\beta$-glucanase production obtained from Eq. 1 are shown in Fig. 1a-c. The maximum extracellular $\beta$-glucanase production was observed in the temperature range of 32.5 to $37.5^{\circ} \mathrm{C}$, at a glucose concentration between 3.5 and $5.5 \%$, and at a pH value between 5.0 and 6.0 , covering the central point of the experiment $\left(35^{\circ} \mathrm{C}, 4 \%\right.$ glucose, and $\left.\mathrm{pH} 5.5\right)$. Thus, these conditions, which are close to the central point, were considered to be optimal for the production of extracellular $\beta$-glucanase by K. marxianus UFV-3. Moreover, according Eq. 1 and Fig. 1a-c, there is an optimal range in which the combination of several factors provides the same optimal result, enabling the selection of an economical level of each factor. The coefficients and $t$ test allowed us to conclude that out of all of the tested factors, $\mathrm{pH}$ had the greatest influence on the production of active extracellular $\beta$-glucanase by $K$. marxianus, followed by cultivation temperature, and the glucose concentration provided a minor contribution.

\section{Effect of $\mathrm{pH}$ and Temperature on $\beta$-Glucanase Activity}

The factors of $\mathrm{pH}$ and temperature significantly influence enzymatic activity. Thus, to determine the $\mathrm{pH}$ and temperature that results in the highest activity of the $\beta$-glucanase secreted by $K$. marxianus UFV-3, initial tests were performed on the culture supernatant to evaluate the effect of these parameters on the $\beta$-glucanase activity. The maximum activity was found at a $\mathrm{pH}$ of 5.0, and the activity decreased when the $\mathrm{pH}$ increased from this point, indicating that acidic $\mathrm{pH}$ values are most appropriate for the performance of this enzyme. In addition, 

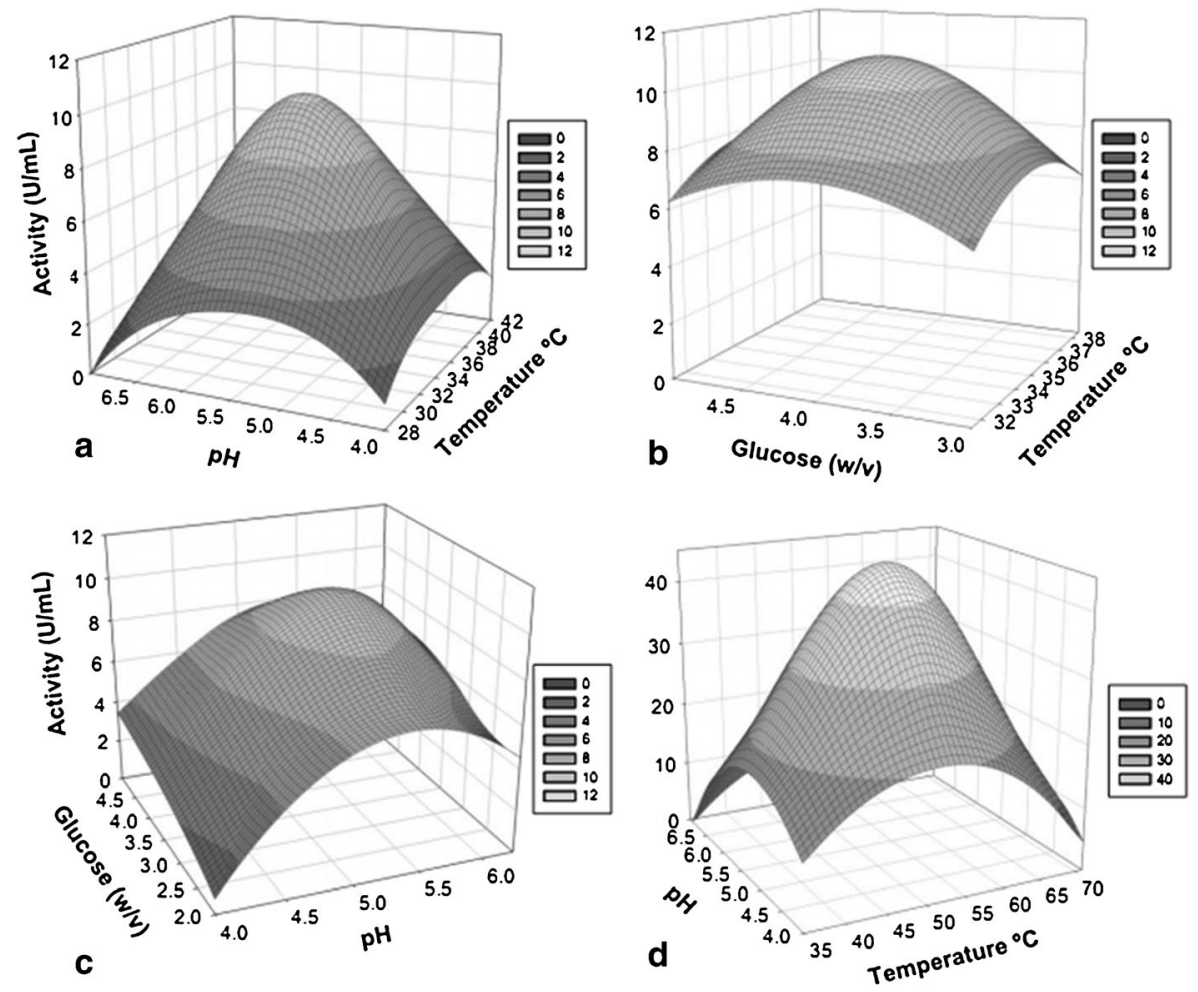

Fig. 1 Response surface plot for the optimization of $\beta$-glucanase production (a-c) and activity (d). Response surface plot for the adjusted activity (units per milliliter) of the $\beta$-glucanase in the culture supernatant and the following factors: $\mathrm{pH}(4.0-7.0)$ and temperature $\left(28-42{ }^{\circ} \mathrm{C}\right)(\mathbf{a})$, glucose $(2-5 \%(w / v))$ and temperature $(28-$ $\left.42{ }^{\circ} \mathrm{C}\right)(\mathbf{b})$, and glucose $(2-5 \%(w / v))$ and $\mathrm{pH}(4.0-7.0)(\mathbf{c})$. d Response surface plot for the adjusted activity (units per milliliter) of $\beta$-glucanase and the $\mathrm{pH}(4.0-7.0)$ and temperature $\left(28-42^{\circ} \mathrm{C}\right)$

increasing the temperature had a positive effect on the enzyme activity up to $60{ }^{\circ} \mathrm{C}$, at which point there was a negative effect, suggesting thermal denaturation (data not shown).

These independent experiments, which were performed with different $\mathrm{pH}$ and temperature values, do not show the effect of the possible interactions between these parameters, and therefore, these results may not match the optimal conditions of this bioprocess. Therefore, to determine the optimal conditions (temperature and $\mathrm{pH}$ ) for the activity of this $\beta$-glucanase, these results were used as the basis for planning a central composite design and to create a response surface model for $\beta$-glucanase activity. Table 2 shows the combinations of the independent variables (temperature and $\mathrm{pH}$ ) and the respective observed and adjusted $\beta$ glucanase activity (units per milliliter) and residual error obtained for each treatment. The second-order polynomial model adjusted for $\beta$-glucanase activity is given in Eq. 2 .

$$
\mathrm{EA}=-578.069+138.07 P+9.61257 T-12.8586 P^{2}-0.0915863 T^{2}
$$

where EA corresponds to enzymatic activity (units), $T$ corresponds to temperature, and $P$ corresponds to $\mathrm{pH}$.

ANOVA indicated that this model was significant $(p=0.001)$, and the $R^{2}$ value indicated that $84.08 \%$ of the observed variation in the $\beta$-glucanase activity can be explained by this model. The contour plot and response surface plot generated from the data are shown in 
Fig. 1d. For the reaction conditions used, the maximal enzymatic activity was observed in the temperature range of 45 to $60{ }^{\circ} \mathrm{C}$ and at a $\mathrm{pH}$ value between 4.8 and 6.0 , spanning the central point of the experiment. Therefore, the combination of the temperature and $\mathrm{pH}$ central point $\left(53{ }^{\circ} \mathrm{C}\right.$ and $\left.\mathrm{pH} 5.5\right)$ was considered optimal for the activity of this $\beta$-glucanase. This broad area of maximum performance allows the exploitation of many combinations of temperature and $\mathrm{pH}$, indicating the potential versatility of this enzyme in various processes.

Fungal $\beta$-glucanases exhibit optimal activity at temperatures between 40 and $60{ }^{\circ} \mathrm{C}$ and at $\mathrm{pHs}$ between 4.5 and $6.0[3,4,7,31]$. The exo- $\beta$-(1,3)-glucanase from Pichia guilliermondii is most active at $\mathrm{pH} 4.5$ and $45{ }^{\circ} \mathrm{C}$. The endo- $\beta$ - $(1,3)$-glucanases from $S$. cerevisiae and Schizosaccharomyces pombe show optimal activity at pH 6.0 and 6.5, respectively [32, 33], values close to those found for the extracellular $\beta$-glucanase in this study.

Partial Purification of $\beta$-Glucanase

The concentrated crude extract showed a specific activity of $113 \mathrm{U} / \mathrm{mg}$ protein, and the specific activity obtained at the end of the partial purification was 3,927.6 U/mg protein, representing a purification factor of 35 , with $50 \%$ recovery of the enzyme.

The concentrated extract was applied to a HiTrap Capto Q column. The fractions with the highest activity were pooled, concentrated in a Vivaspin column (10 kDa MWCO), and analyzed by SDS-PAGE (Fig. 2). A significant concentration of two proteins approximately $45 \mathrm{kDa}$ was subsequently identified as being similar to $\beta$-glucanases. However, even at low concentrations, four contaminating proteins were observed in the sample. Three proteins had a molecular weight of approximately $97 \mathrm{kDa}$, and one protein was approximately $31 \mathrm{kDa}$.

Analysis by Mass Spectrometry

The two bands observed near $45 \mathrm{kDa}$ (Fig. 2) were excised from the gel, subjected to tryptic digestion, and analyzed by MALDI-TOF/TOF mass spectrometry. The MS1 mass spectra

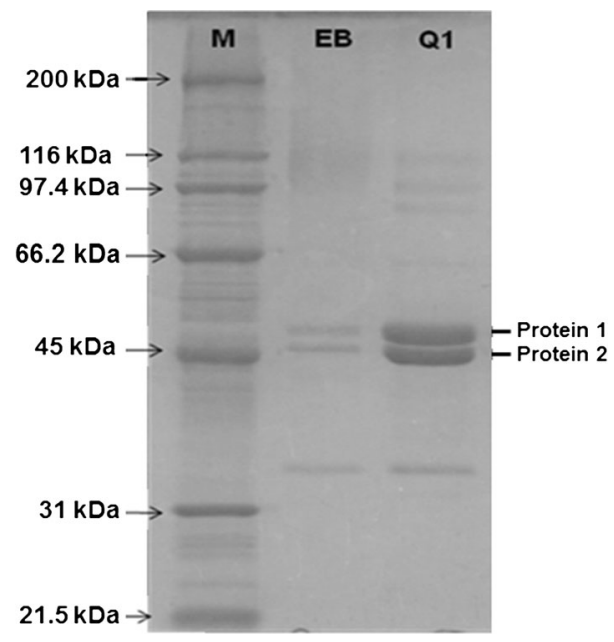

Fig. 2 Anion exchange chromatography of the concentrated culture supernatant using a HiTrap Capto Q column. SDS-PAGE analysis of the purified $\beta$-glucanase secreted from $K$. marxianus. The gel was stained with Coomassie brilliant blue G-250. Lane 1, molecular mass marker; Lane 2, culture supernatant concentrated by ultrafiltration; Lane 3, proteins obtained after Capto Q ion exchange and concentration by ultrafiltration 
were processed and compared using the Flex Analysis package (Bruker Daltonics). The peptide mass fingerprinting was the same for both proteins, indicating the presence of two $\beta$-glucanase isoforms. The tryptic digestion was also analyzed by micrOTOF-Q (Bruker Daltonics), and the MS2 spectra were used for protein sequencing using the Mascot algorithm against a public database. The sequences of the identified peptides were additionally verified manually by de novo sequencing and aligned with the $\beta$-glucanases in the database, with 28 MS/MS spectra identified for 6 peptide sequences and $35 \%$ of putative protein coverage. A NCBI BLAST search revealed the presence of domains of the cellulase and endo-glucanase superfamilies. The amino acid alignment using the Clustal algorithm showed this sequence as a new glucosidase, sharing similarities with 1,3- $\beta$-glucanases (Fig. 3).

\section{Substrate Specificity of the $\beta$-Glucanase}

The partially purified $\beta$-glucanase showed low rate of hydrolysis $(0-4 \%)$ for the substrates $p \mathrm{NP} \alpha \mathrm{G}, p \mathrm{NP} \beta \mathrm{Man}, p \mathrm{NP} \alpha \mathrm{Man}, p \mathrm{NP} \beta \mathrm{Gal}, p \mathrm{NP} \alpha \mathrm{Gal}, \mathrm{mNP} \alpha \mathrm{Gal}$, oNP $\alpha \mathrm{Gal}$, and $p \mathrm{NP} \alpha \mathrm{Ara}$ compared to $p \mathrm{NP} \beta \mathrm{G}(100 \%)$ (Table 3$)$. The hydrolysis of the substrates $p \mathrm{NP} \beta \mathrm{Cb}, p \mathrm{NP} \beta \mathrm{Xyl}$, and $p \mathrm{NP} \beta \mathrm{G}$ was 28,16 , and $6.5 \%$, respectively.

These results show the high specificity of this $\beta$-glucanase for substrates with a $\beta$-anomeric configuration as it was not efficient in hydrolyzing any of the $\alpha$-glycosidic substrates tested.

$\begin{array}{llllllllll}10 & 20 & 30 & 40 & 50 & 60 & 70 & 80 & 90 & 100\end{array}$

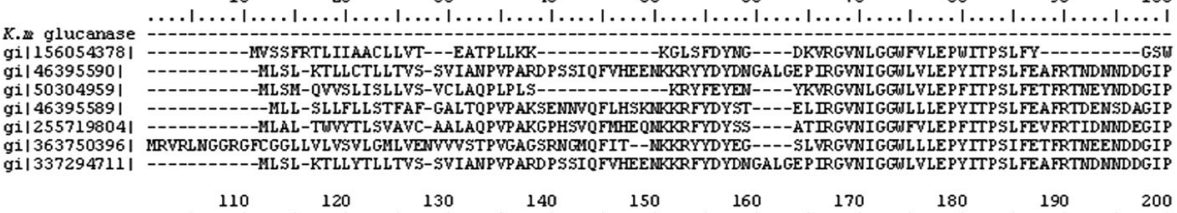

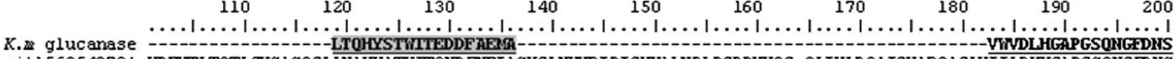

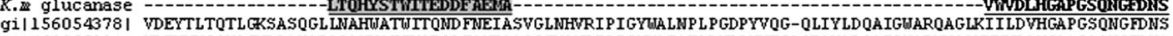
gi|46395590। VDEYHYCOYLGN LAKSRLQSHWSTFYOEDDFANIASOGFNLVRIPIGYWAFATLDNDPYVTGLOESYLDOAIGWARNNSLKVUVDLHGAAGSONGFDNS gi| 50304959| YDEYHYCOYLEED LARDRLKOHWSTWTTEAD FEDISNTGLNTVRIPIGYWAFE L LDDDPYVSGLQEA YLDOAIEUARSYGLKVWVD LHGA PGSONGFDNS gi| 46395589 | VDEYHYCEALGSEVAESRLEAHUSTFYTED FKNIASAGLNYVIPIGYTAFKTLDSDPYVTGKOESYLDKAIOWSKDAGLKVWVLHGA PGSONGDDNS gi $\mid 255319804$ | ADEYHYCQALGQEVAASRLEOHUSSWFTEKD FANIADSGLNFVRIPIGYWAFKTLESDPYTTGOEYYLDQAIGUARNNGLKVWVDLHGAAGSONGFDNS gi| 363750396 | VDEYHFCSYLGOEVARDRLVAHWETFYKEED FHNIAAAGLNLVRIPIGYUA FETLDSDPYVSGYOEGYLDQA IFUARRAGLKVWVDLHGA PGSONGFDNS gi|337294711 | VDEYHYCOSLGDLAKSRLESHUSTFYQEODFANIASQGFNLVRIPIGYTAFETLDNDPYVTGIOESYLDOAIGWARNNSLKVWVDLHGAAGSONGFDNS

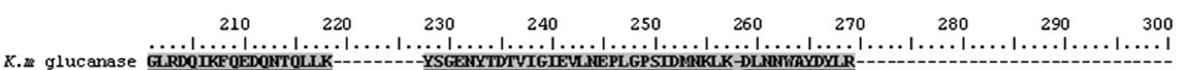

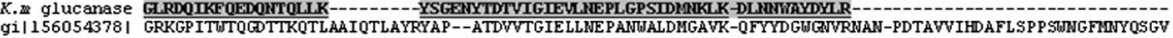
gi| 46395590| GLRDSYE FLEDSNLAVTTKALWY I LKKYSAEEYLDTVIGIELINEPLGPVLDHDKMKNDYLLPAYEYLRNTIESNDIIIIMHDAFOQFNYUDD FFTETD GY

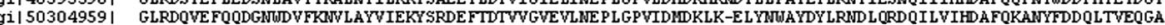
gi| 46395589| GLRDHWSFLEDENLNLTKEVIKYLLEKYSREEYLDTVIGIELINEPLGPVDDHDKLK-EYYOFGYDYLRNE LSDQIVVIHDAFEAYNYUDSTLTVED GS gi 1255719804 | GLRDSYAFLEDSNLALTKEVLOYLLEKYSRDEYLDTVIGVELINEPLGPVLDHDKLK-EYYQFGYDYLRNE LGDDIVI IHDAFEPYNYUDDTLVYNOGA gi $\mid 363750396$ | GLRGOVOFLEGENFE LLKRVVRYMIEKYSRDYYSDVVIGVOVLNEPLGTAVDMGKVK-ELYYYAYDTLRNEMGRDO IMVIHDAFMAPHYUDDOFTLEGGY

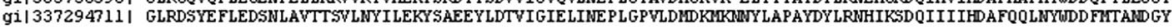

310 320 330 340 350 360 370 380 390 400

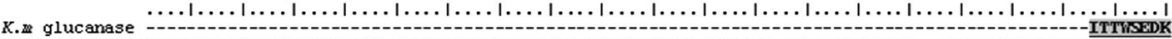
gi| 156054378 | NDIILDTHIYQIFSFAEVAMKPCQHVOVACSOIGNLANTDKUTIVGEFSGAOTDCAKULWGFGVSRYDGSYPGS---PAVYGSCQTKDVGTVDGL LAID gi| 46395590 | WGVTIDHHHYOVFDSOLESSWDEHIOVACOWGTGVLDEAHUTVCGEFAAALTD CTKWVWSVGFGARYDGSWWNGDETSTYIGSCAMNDD--ITSWSDOR gi|50304959| FGVLVHHHYVFSPEEVGTIDEHISWCE QGKTLTEAHWWWGEWSAALTD CTKWLNGVGIGARYD GSFVKNQDTSYUI GSCEGSOD--ISTWTSDK gi|46395589| UGWWDHHHYOCFSSDQLARSIDEHVSVACEWGTGVLTESHUTVAGEUSAALTDCAKUINGVGYGARYDGSFTKDSESSYYIGSCENNED--VSTUSEER gi gi $255719804 \mid$ WGVWDHHHYVFSNKE LLRSIDEHVSVACE WGSGTLSEAHWTVCGEWSAALTDCAKWLNGVGYGHRYD GTFHKGDDTSSYI GSCEMNED--INSWSDER

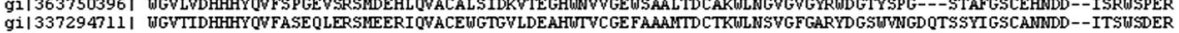

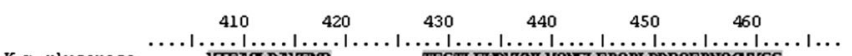
K.MI glucanase -- -YIEAOCDAYEIR-gi 1156054378 | KVNLAY FMEAOLDAYEAHSGWVFUTWKTESAPE WHFONLTRAGLIPOPLTSRKYGKOCATSTCLIPGN

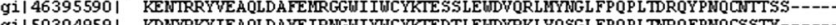
gi 50304959 | KSNRKVYEAOLDAFE LRGGUI FUCYKTETTVEUDLORLMYSGLFPOPVTDROYPNOCGF----gi 4639558 | KSNNRKYVEALDAFELRGGUIFUCYKTETTVEUDLQRLMYSGLFPQPVIDROY PNQCGF------Gi|255719804| KADTRKYVAOLDAFLLRGGWIUTMTETSLEWDLORLMFNGLFPOPVIDROYPNQCGFSN----gi|337294711। KENTRRYVEAQLDAFEMRGGUIIUCYKTESSLEUDVQRLYYNGLFPQPLTAROYPNOCNTTSN----

Fig. 3 Alignment of data bank sequences presenting similarity to the six peptides obtained by MS/MS sequencing of the $K$. marxianus $\beta$-glucanase. Dashed boxes indicate de novo peptide sequences. Other sequences and their accession numbers are shown in the figure 
Table 3 Beta-glucanase specificity

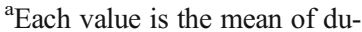
plicate experiments

\begin{tabular}{ll}
\hline Substrates $(2 \mathrm{mM})$ & Relative activity $(\%)^{\mathrm{a}}$ \\
\hline$p \mathrm{NP}-\beta$-D-glucopyranoside (control) & 100 \\
$p \mathrm{NP}-\beta$-D-cellobioside & $28.2 \pm 4.45$ \\
$p \mathrm{NP}-\beta$-D-xylopyranoside & $16.2 \pm 0.03$ \\
$p \mathrm{NP}-\beta$-D-mannopyranoside & $4.0 \pm 0.17$ \\
$p \mathrm{NP}-\alpha$-D-galactopyranoside & $3.8 \pm 0.35$ \\
$p \mathrm{NP}-\alpha$-D-glucopyranoside & $3.2 \pm 0.12$ \\
$p \mathrm{NP}-\alpha$-D-mannopyranoside & $2.9 \pm 0.78$ \\
$p \mathrm{NP}-\beta$-D-galactopyranoside & $2.7 \pm 0.03$ \\
$p \mathrm{NP}-\alpha$-D-arabinopyranoside & $2.6 \pm 0.12$
\end{tabular}

The results also show that the $\beta$-glucanase from $K$. marxianus has a high specificity for $\beta$ glycosidic bonds, a low specificity for $\beta$-xylosidic bonds, and no activity on sugars containing mannose, galactose, or arabinose (Table 3).
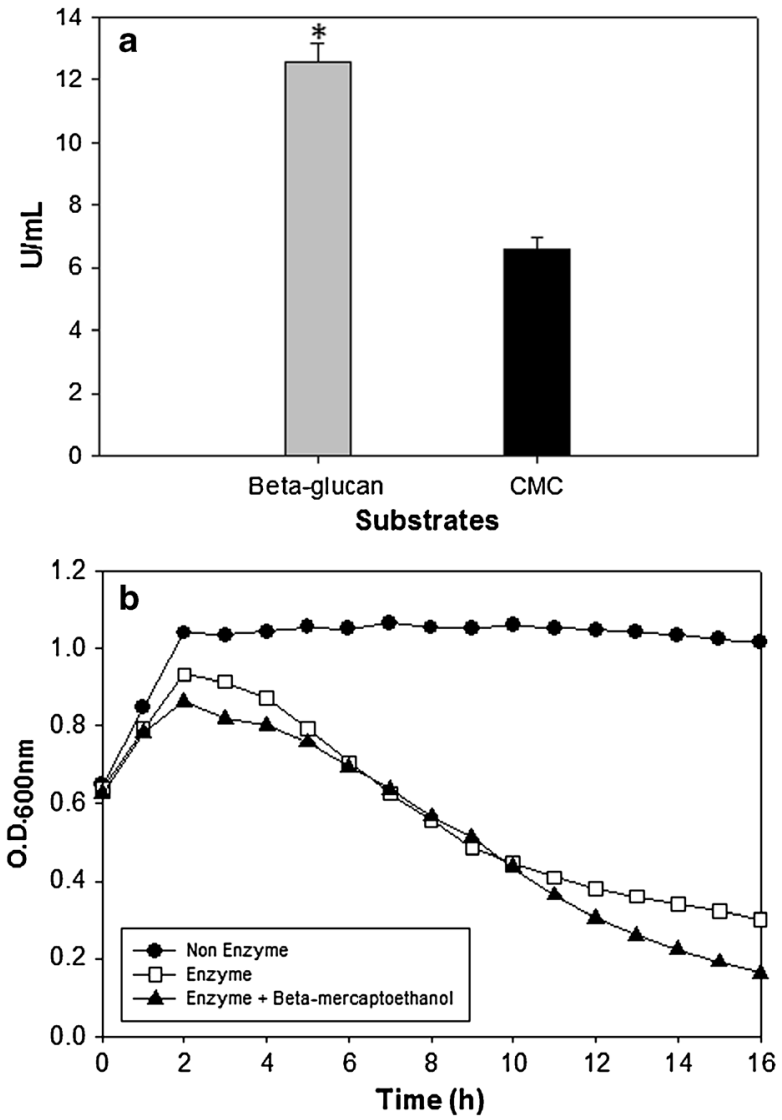

Fig. 4 a $\beta$-Glucanase activity on $\beta$-glucan $(\beta-1,3: \beta-1,4)$ and CMC $(\beta-1,4)$. Data are presented in nanomoles Glc per minute per milliliter of culture media. b Lytic activity of the culture supernatant on $S$. cerevisiae with or without $\beta$-mercaptoethanol 
When evaluating the activity of the $\beta$-glucanase on $\mathrm{CMC}$ and $\beta$-glucan, the activity for $\beta$ glucan was almost twofold greater than that for $\mathrm{CMC}$, indicating its greater specificity for $\beta$ 1,3 and $\beta-1,4$ bonds (Fig. 4a). In these tests, there was no glucose production, which suggests that the secreted enzyme is an endo-glucanase. These results suggest that this enzyme is $\beta$ 1,3(4)-glucanase. This type of glucanase hydrolyzes $\beta$-1,3-glucans, $\beta$-1,4-glucans, and $\beta$-1,3glucans [5]. The lytic activity of the culture supernatant on $S$. cerevisiae was accompanied by a reduction in the optical density at $600 \mathrm{~nm}$. As shown in Fig. 4b, the optical density of the $S$. cerevisiae culture was reduced when it was incubated in the presence of the enzyme extract. The activity of the $\beta$-glucanase on the yeast cell wall can be explained by the specificity of this enzyme to hydrolyze of $\beta-1,3$ glycosidic linkages [18].

\section{Conclusions}

An extracellular $\beta$-glucanase expressed and secreted by $K$. marxianus was identified for the first time. The optimal conditions to produce $\beta$-glucanase were a glucose concentration of $4 \%$ $(w / v)$, a $\mathrm{pH}$ of 5.5 , and an incubation temperature of $35^{\circ} \mathrm{C}$. The highest enzyme activity was obtained at a $\mathrm{pH}$ of 5.5 and $55^{\circ} \mathrm{C}$. After optimizing the culture conditions for $\beta$-glucanase production, the resulting culture supernatant was found to be effective in digesting the cell wall of the yeast $S$. cerevisiae, indicating that this $\beta$-glucanase possesses great potential for the biotechnological production of soluble $\beta$-glucan and protoplasts from yeast cells.

Acknowledgments This research was supported by the Conselho Nacional de Desenvolvimento Científico e Tecnológico, Fundação de Amparo a Pesquisa do Estado de Minas Gerais, and Coordenação de Aperfeiçoamento de Pessoal de Nível Superior.

\section{References}

1. Tsai, L. C., Chen, Y. N., \& Shyur, L. F. (2008). Structural modeling of glucanase-substrate complexes suggests a conserved tyrosine is involved in carbohydrate recognition in plant 1,3-1,4-beta-D-glucanases. Journal of computer-aided molecular design, 22, 915-923.

2. Fukuda, K., Hiraga, M., Asakuma, S., Arai, I., Sekikawa, M., \& Urashima, T. (2008). Purification and characterization of a novel exo- $\beta$-1,3-1,6-glucanase from the fruiting body of the edible mushroom enoki (Flammulina velutipes). Bioscience, Biotechnology, and Biochemistry, 72, 3107-3113.

3. Sutivisedsak, N., Leathers, T. D., Bischoff, K. M., Nunnally, M. S., \& Peterson, S. W. (2013). Novel sources of beta-glucanase for the enzymatic degradation of schizophyllan. Enzyme and Microbial Technology, 52, 203-210.

4. Luo, H., Yang, J., Yang, P., Li, J., Huang, H., Shi, P., Bai, Y., Wang, Y., Fan, Y., \& Yao, B. (2010). Gene cloning and expression of a new acidic family 7 endo-beta-1,3-1,4-glucanase from the acidophilic fungus Bispora sp. MEY-1. Applied Microbiology and Biotechnology, 85, 1015-1023.

5. Boyce, A., \& Walsh, G. (2007). Production, purification and application-relevant characterisation of an endo1,3(4)-beta-glucanase from Rhizomucor miehei. Applied Microbiology and Biotechnology, 76, 835-841.

6. Peng, Y., Liu, G.-L., Yu, X.-J., Wang, X.-H., Jing, L., \& Chi, Z.-M. (2010). Cloning of exo- $\beta$-1,3-glucanase gene from a marine yeast Williopsis saturnus and its overexpression in Yarrowia lipolytica. Marine Biotechnology, 13, 193-204.

7. Liu, G., Qin, Y., Hu, Y., Gao, M., Peng, S., \& Qu, Y. (2013). An endo-1,4-beta-glucanase PdCel5C from cellulolytic fungus Penicillium decumbens with distinctive domain composition and hydrolysis product profile. Enzyme and Microbial Technology, 52, 190-195.

8. Blasco, L., Veiga-Crespo, P., Poza, M., \& Villa, T. G. (2006). Hydrolases as markers of wine aging. World Journal of Microbiology and Biotechnology, 22, 1229-1233.

9. Brufau, J., Francesch, M., \& Pérez-Vendrell, A. M. (2006). The use of enzymes to improve cereal diets for animal feeding. Journal of the Science of Food and Agriculture, 86, 1705-1713. 
10. Bamforth, C. W. (2009). Current perspectives on the role of enzymes in brewing. Journal of Cereal Science, 50, 353-357.

11. Daenen, L., Saison, D., Sterckx, F., Delvaux, F. R., Verachtert, H., \& Derdelinckx, G. (2008). Screening and evaluation of the glucoside hydrolase activity in Saccharomyces and Brettanomyces brewing yeasts. Journal of Applied Microbiology, 104, 478-488.

12. Iorio, E., Torosantucci, A., Bromuro, C., Chiani, P., Ferretti, A., Giannini, M., Cassone, A., \& Podo, F. (2008). Candida albicans cell wall comprises a branched beta-D-(1->6)-glucan with beta-D-(1->3)-side chains. Carbohydrate Research, 343, 1050-1061.

13. Fleuri, L. F., \& Sato, H. H. (2008). ß-1,3 Glucanases e quitinases: aplicação na lise de leveduras e inibição de fungos. Ciênc agrotec, 32, 1224-1231.

14. Barbosa, A. M., Cunha, P. D. T., Pigatto, M. M., \& Silva, M. L. C. (2004). Produção e Aplicações de Exopolissacarídeos Fúngicos Production and Applications of Fungal Exopolysaccharides. Semina: Ciências Exatas e Tecnológicas, 25, 29-42.

15. Behall, K. M. (2006). Consumption of both resistant starch and -glucan improves postprandial plasma glucose and insulin in women. Diabetes Care, 29, 976-981.

16. Kim, S. Y., Song, H. J., Lee, Y. Y., Cho, K., \& Roh, Y. K. (2006). Biomedical issues of dietary fiber $\beta$ glucan. Journal of Korean Medical Science, 21, 781-789.

17. Giese, E. C., Barbosa, A. M., \& Dekker, R. F. H. (2010) Pathways to bioactive oligosaccharides: biological functions and potential applications. In: R. Ito \& Y. Matsuo (Eds.), Handbook of carbohydrate polymers: development, properties and applications (pp. 279-309). New York: Nova Science Publishers.

18. Kim, K. S., \& Yun, H. S. (2006). Production of soluble $\beta$-glucan from the cell wall of Saccharomyces cerevisiae. Enzyme and Microbial Technology, 39, 496-500.

19. Aimanianda, V., Clavaud, C., Simenel, C., Fontaine, T., Delepierre, M., \& Latge, J. P. (2009). Cell wall beta$(1,6)$-glucan of Saccharomyces cerevisiae: structural characterization and in situ synthesis. The Journal of Biological Chemistry, 284, 13401-13412.

20. Chaidedgumjorn, A., Toyoda, H., Woo, E. R., Lee, K. B., Kim, Y. S., Toida, T., \& Imanari, T. (2002). Effect of (1-3)- and (1-4)-linkages of fully sulfated polysaccharides on their anticoagulant activity. Carbohydrate Research, 337, 925-933.

21. Fonseca, G. G., Heinzle, E., Wittmann, C., \& Gombert, A. K. (2008). The yeast Kluyveromyces marxianus and its biotechnological potential. Applied Microbiology and Biotechnology, 79, 339-354.

22. Yoshida, E., Hidaka, M., Fushinobu, S., Koyanagi, T., Minami, H., Tamaki, H., Kitaoka, M., Katayama, T., \& Kumagai, H. (2009). Purification, crystallization and preliminary X-ray analysis of beta-glucosidase from Kluyveromyces marxianus NBRC1777. Acta crystallographica Section F, Structural biology and crystallization communications, 65, 1190-1192.

23. Yoshida, E., Hidaka, M., Fushinobu, S., Koyanagi, T., Minami, H., Tamaki, H., Kitaoka, M., Katayama, T., \& Kumagai, H. (2010). Role of a PA14 domain in determining substrate specificity of a glycoside hydrolase family 3 beta-glucosidase from Kluyveromyces marxianus. The Biochemical Journal, 431, 39-49.

24. Smith, P. K., Krohn, R. I., Hermanson, G. T., Mallia, A. K., Gartner, F. H., Frovenzano, M. D., Fujimoto, E. K., Goeke, N. M., Olson, B. J., \& Klenk, D. C. (1985). Measurement of protein using bicinchoninic acid. Analytical Biochemistry, 150, 76-85.

25. Miller, G. L. (1959). Use of dinitrosalicylic acid reagent for determination of reducing sugar. Analytical Chemistry, 31, 426-428.

26. Kalil, S. J., Maugeri, F., \& Rodrigues, M. I. (2000). Response surface analysis and simulation as a tool for bioprocess design and optimization. Process Biochemistry, 35, 539-550.

27. Barbosa, A. M., Giese, E. C., Dekker, R. F., Borsato, D., Briones Perez, A. I., \& Ubeda Iranzo, J. F. (2010). Extracellular beta-glucosidase production by the yeast Debaryomyces pseudopolymorphus UCLM-NS7A: optimization using response surface methodology. New Biotechnology, 27, 374-381.

28. Yin, T. (2010). Optimized medium improves expression and secretion of extremely thermostable bacterial xylanase, XynB, in Kluyveromyces lactis. Journal of Microbiology and Biotechnology, 20, 1471-1480.

29. Dairot, D. J., Simontetti, A., Hertz, P. F., \& Brandelli, A. (2008). Purification and characterization of an extracellular $\beta$-glucosidase from Monascus purpureus. Journal of Microbial biotechnology, 18, 933-941.

30. Fuentes, L. L., Rabelo, S. C., Filho, R. M., \& Costa, A. C. (2011). Kinetics of lime pretreatment of sugarcane bagasse to enhance enzymatic hydrolysis. Applied Biochemistry and Biotechnology, 163, 612-625.

31. O’Connell, E., Piggott, C., \& Tuohy, M. (2011). Purification of exo-1,3-beta-glucanase, a new extracellular glucanolytic enzyme from Talaromyces emersonii. Applied Microbiology and Biotechnology, 89, 685-696.

32. So, J., \& Rhee, I. (2010). Molecular cloning and functional expression of an extracellular exo- $\beta-(1,3)-$ glucanase from Pichia guilliermondii K123-1. Journal of Korean Society for Applied Biological Chemistry, $53,356-363$.

33. Martin-Cuadrado, A. B., Fontaine, T., Esteban, P. F., del Dedo, J. E., de Medina-Redondo, M., del Rey, F., Latge, J. P., \& de Aldana, C. R. (2008). Characterization of the endo-beta-1,3-glucanase activity of S. cerevisiae Eng2 and other members of the GH81 family. Fungal Genetics and Biology : FG \& B, 45, 542-553. 